\title{
A correlation between characteristics and students' perception with the last score of field experience study at community based medicine
}

\author{
Marisa Anggraini ${ }^{1}$, Abdul Latief ${ }^{2}$
}

\begin{abstract}
Abstrak
Pengalaman belajar lapangan $(P B L)$ merupakan salah satu dari program pembelajaran berbasis masyarakat yang dilaksanakan di Fakultas Kedokteran Universitas Malahayati (FK UNIMAL). Tujuan penelitian ini untuk mengidentifikasi beberapa faktor yang paling mempengaruhi nilai akhir mata ajaran PBL. Kuesioner dibagikan kepada seluruh mahasiswa FK UNIMAL yang mengambil FES pada semester genap tahun 2007. Pengambilan data dilakukan pada tanggal 3 September 2007. Data dianalisis dengan STATA versi 9.0 menggunakan metode regresi Cox. Penelitian ini diikuti oleh semua mahasiswa FK UNIMAL sebanyak 108 orang. Gender, nilai kumulatif, dan ketepatan mahsiswa mengikuti PBL mempengaruji nilai akhir PBL. Mahasiswa yang mempunyai nilai kumulatif sebelumnya yang tinggi dibandingkan dengan yang rendah berpeluang $72 \%$ untuk mendapat nilai akhir PBL yang tinggi [risiko relatif suaian $(R R a)=1,72 ; 95 \%$ intrval kepercayaan $(C I)=1,22-2,43$ ). Sedangkan mahasiswa perempuan dibandingkan mahsiswa laki-laki mempunyai kemungkinan 39\% mendapat nilai yang lebih besar $(R R a=1,39 ; 95 \% C I=0,93-2,09 ; P=0,111) . \quad$ Mahasiswa yang mengambil PBL tepat waktu dibandingkan dengan tidak tepat waktu mempunyai peluang 29\% nilai FES lebih baik (RR = 1,29; CI = 0,96-1,73; $P=0$,088). Pada PBL, perhatian khusus perlu diberikan kepada mashasiswa dengan nilai kumulatif sebelumnya yang kurang untuk meningkatkan nilai performa mereka. (Med J Indones 2008; 17: 64-7)
\end{abstract}

\begin{abstract}
Field experience study (FES) is one of the Community Based Medicine Education Programs that has done in Faculty of Medicine University of Malahayati. The aims of this study were to identify several factors related to final FES score. The questionnaires were given for all field study participants. It consisted of students' characteristics and perception on field study. This FES was conducted on 3 September 2007. Cox regression was used to analyze data using STATA version 9.0. Gender, previous GPA, time of taking FES was dominant risk factors related to risk of FES score. The students who had higher cumulative Grade Point Average (GPA) had 72\% higher on final FES score [adjusted relative risk $(R R a)=1.72 ; 95 \%$ Confidence interval $(C I)=1.22-2.43)$. Female than male students had 39\% higher final FES score $(R R a=1.39 ; 95 \% C I=0.93-2.09 ; P=0.111)$, and the students who took than who did not take FES on recommended year of study had 29\% higher final FES score $(R R=1.29 ; 95 \% C I=0.96-1.73 ; P=0.088)$. While conducting FES, special attention should be given to students who had previous GPA in order to increase their final FES score. (Med J Indones 2008; 17: 64-7)
\end{abstract}

Keywords: community-based medicine, field experience study, student's performance

The medical educational strategies applied in a competency based curriculum, among other, is community-based oriented. Medical education should be respond community needs and produce medical doctor who appropriate with health service needs in

\footnotetext{
${ }^{1}$ Department of Community Medicine, University of Malahayati Medical School, Bandar Lampung, Indonesia

${ }^{2}$ Department of Child Health, Faculty of Medicine, University of Indonesia Dr. Cipto Mangunkusumo General Hospital, Jakarta, Indonesia
}

the community served. ${ }^{1,2}$ One of the ways to reach the goal of community based medicine which is known as Pengalaman Belajar Lapangan or PBL (Field Experience Study $=$ FES). The students are encouraging to conduct FES appropriately.

The student final FES score was influenced by seeveral factors, such as several student's characteristics, knowledge, skill, perception on FES. By identifying and controlling several dominant factors related to final score, it will improve the performance of the students. The objective of this research was to identify several risk factors related to FES final score. 


\section{METHODS}

The Ethical Committee of the Medicine Faculty University of Indonesia approved this study. The study was a cross sectional design. The subjects were Unimal Medicine Faculty students who took FES session on even semester in 2006-2007. The data was taken at Unimal Medicine Faculty on September 3' 2007 by using valid and reliable questioner. Informed consent was obtained from study participant, then students did not have to write their names in order to make questioner more objective.

The questioner was about some characteristics (gender, age, cumulative GPA when they took FES session and either taking FES session on time), and student's perception about FES lecture.

The perception was about provision theory, provision clearness, knowledge in research methodology, knowledge in epidemiology, skills in developing research proposal, skills in data entry, view about health problem, cooperative people, time to go to the field, role of lecturers in the field, duration to make report, and preference on FES lecture. The depth of theory, clearness of provision theory, view about health problem, knowledge in epidemiology and methodology were chosen because by having good provision would help students understand and achieve good results on FES exam.

With sufficient time for research, cooperative people involve in the research, sufficient skill in making proposal and data, it was hoped that the students were able to have good grades in the research as one of the components in FES score. The students' preferences to FES lecture also included in the list of questions since the grade would influenced by their preferences. The students gave score from $0-100$ for each question. Zero was for the worst and 100 for the best.

The final FES score was a summation of final multiple choice question (MCQ) examination (weighted 60\%), student's report (weighted 30\%) and student oral presentation (weighted 10\%). Good final FES score was considered if the student 75 or more final FES scores. Regression Cox by STATA version $9.0^{3}$ was used to identify the risk of final FES score.

\section{RESULTS}

All of the students (108) having joined FES lecture participated this study and filled the questioners. The bad and good scores were similarly distributed in term of Age group, knowledge, skills, perception, and preference. Most of students liked FES lecture, and it was not varied [coefficient variation of 10.4\% (9.52/90.43)]. The students suggested that the provision from the lecturer was clear enough and the handbook was, too. Besides, the epidemiology provision should be improved. The extra on FES lecture at Medicine Faculty of Unimal were give to role of advisor who helped the students in the field (Table 1).

Table 2 shows that gender, previous GPA, time of taking FES was dominant risk factors related to risk of FES score. Those who had high than low previous GPA had $72 \%$ risk to be FES good score. In tern of gender, female than male students had a 39\% higher risk to be FES good score $(\mathrm{P}=0.111)$. Furthermore, in term of taking FES session on time, those who took than on time than did not on time had $29 \%$ higher risk to be FES good score $(\mathrm{P}=0.088)$.

\section{DISCUSSION}

There were some limitations in this study. The questioner was done at the end of FES program. It was done in order to make all of the students would participate in the research. Since all of the lecturers of $F E S$ came to "the questioner session", there was a tendency that the students did not fill the questioner freely. Because of this weakness, the students did not write their names on the questioner.

Our study reveals that students who had high GPA had better final score. This is in accordance with previous studies that GPA influenced by the final score. ${ }^{5,6}$

Our study showed, it could be seen that female students had more chances to get better score, and the results was similar with previous studies. ${ }^{7,8,9}$ Students who took FES lecture on time had $29 \%$ better grade on FES ( RR $=1.29 ; \mathrm{CI}=0.96-1.73 ; \mathrm{P}=0.088)$. The reasons for chances of this smart students usually take FES lecture on time, and usually the ones who are less smart took FES lecture in the last semester because they had to take prerequisite lectures first.

The interesting part of the research which was done at Medicine Faculty of Unimal was age did not influence the last grade of FES lecture. However, several previous studies found that age influenced the last grade. ${ }^{7,10,11}$ There was a difference in age division. In this study, perception did not influence the time score. And it was contradicted with this study theory which mentioned perception influenced students performance. ${ }^{7}$ It seems that the average of students perception was good enough (average $=78.4$ ). 
Table 1. Age group, knowledge, skill, perception, preference and risk of FES score

\begin{tabular}{|c|c|c|c|c|c|c|c|}
\hline & \multicolumn{4}{|c|}{ Score of FES } & \multirow{3}{*}{$\begin{array}{l}\text { Crude } \\
\text { relative risk }\end{array}$} & \multirow{3}{*}{$\begin{array}{c}95 \% \text { Confidence } \\
\text { intervals }\end{array}$} & \multirow{3}{*}{$\mathrm{P}$} \\
\hline & \multicolumn{2}{|c|}{ Bad score $[\mathrm{N}=44)$} & \multicolumn{2}{|c|}{ Good score $[\mathrm{N}=64)$} & & & \\
\hline & $\mathrm{n}$ & $\%$ & $\mathrm{n}$ & $\%$ & & & \\
\hline \multicolumn{8}{|l|}{ Age } \\
\hline 22.-26 years & 24 & 45.3 & 29 & 54.7 & 1.00 & Reference & \\
\hline $19-22.5$ years & 20 & 36.4 & 35 & 63.6 & 1.16 & $0.71-1.90$ & 0.548 \\
\hline \multicolumn{8}{|l|}{ Provision theory } \\
\hline Poor & 23 & 43.4 & 30 & 56.6 & 1.00 & Reference & \\
\hline Good & 21 & 38.2 & 34 & 61.8 & 1.09 & $0.66-1.78$ & 0.725 \\
\hline \multicolumn{8}{|l|}{ Provision clearness } \\
\hline Poor & 8 & 34.8 & 15 & 65.2 & 1.00 & Reference & \\
\hline Good & 36 & 42.4 & 49 & 57.7 & 0.88 & $0.50-1.58$ & 0.676 \\
\hline \multicolumn{8}{|c|}{ Knowledge in research } \\
\hline methodology & 33 & $\begin{array}{l}42.3 \\
367\end{array}$ & $\begin{array}{l}45 \\
19\end{array}$ & $\begin{array}{l}57.7 \\
63.3\end{array}$ & 1.00 & Reference & \\
\hline $\begin{array}{l}\text { Poor } \\
\text { Good }\end{array}$ & 11 & 36.1 & 19 & 03.3 & 1.10 & $0.64-1.88$ & 0.733 \\
\hline \multicolumn{8}{|c|}{ Knowledge in epidemiology } \\
\hline Poor & 33 & 39.3 & 51 & 60.7 & 1.00 & Reference & \\
\hline Good & 11 & 45.8 & 13 & 54.2 & 0.89 & $0.49-1.64$ & 0.713 \\
\hline \multicolumn{8}{|c|}{ Skills in making proposal } \\
\hline Poor & 30 & 39.0 & 47 & 61.0 & 1.00 & Reference & \\
\hline Good & 14 & 45.2 & 17 & 54.8 & 0.99 & $0.51-1.56$ & 0.705 \\
\hline \multicolumn{8}{|c|}{ Skills in doing the data } \\
\hline Poor & 32 & 40.5 & 47 & 59.5 & 1.00 & Reference & \\
\hline Good & 12 & 41.4 & 17 & 58.6 & 0.99 & $0.57-1.72$ & 0.958 \\
\hline \multicolumn{8}{|c|}{ View about health problem } \\
\hline Poor & 22 & 39.3 & 34 & 60.7 & 1.00 & Reference & \\
\hline Good & 22 & 42.3 & 30 & 57.7 & 0.95 & $0.58-1.55$ & 0.838 \\
\hline \multicolumn{8}{|l|}{ Cooperative people } \\
\hline Not cooperative & 13 & 37.1 & 22 & 62.9 & 1.00 & Reference & \\
\hline Cooperative & 31 & 42.5 & 42 & 57.5 & 0.92 & $0.55-1.53$ & 0.737 \\
\hline \multicolumn{8}{|c|}{ Juration of the field study } \\
\hline Poor & 23 & 44.2 & 29 & 55.8 & 1.00 & Reference & \\
\hline Good & 21 & 37.5 & 35 & 62.5 & 1.12 & $0.69-1.83$ & 0.650 \\
\hline \multicolumn{8}{|c|}{ Role of lecturers in the field } \\
\hline Poor & 10 & 47.6 & 11 & 52.4 & 1.00 & Reference & \\
\hline Good & 34 & 39.1 & 53 & 60.9 & 1.16 & $0.61-2.22$ & 0.649 \\
\hline \multicolumn{8}{|c|}{ Preference on FES lecture } \\
\hline No & 4 & 40.0 & 6 & 60.0 & 1.00 & Reference & \\
\hline Yes & 40 & 40.9 & 58 & 59.3 & 0.99 & $0.42-2.29$ & 0.975 \\
\hline
\end{tabular}

Tabel 2. Relationship between gender, previous GPA, time of taking FES and risk of FES score

\begin{tabular}{|c|c|c|c|c|c|c|c|}
\hline & \multicolumn{4}{|c|}{ Score of FES } & \multirow{3}{*}{$\begin{array}{l}\text { Adjusted } \\
\text { relative risk* }\end{array}$} & \multirow{3}{*}{$\begin{array}{c}95 \% \\
\text { Confidence } \\
\text { intervals }\end{array}$} & \multirow{3}{*}{$\mathrm{P}$} \\
\hline & \multicolumn{2}{|c|}{$\begin{array}{c}\text { Bad score } \\
{[\mathrm{N}=44)}\end{array}$} & \multicolumn{2}{|c|}{$\begin{array}{c}\text { Good score } \\
{[N=64)}\end{array}$} & & & \\
\hline & $\mathrm{n}$ & $\%$ & $\mathrm{n}$ & $\%$ & & & \\
\hline \multicolumn{8}{|l|}{ Gender } \\
\hline Male & 20 & 57.1 & 15 & 42.9 & 1.00 & Reference & \\
\hline Female & 24 & 32.9 & 49 & 67.1 & 1.39 & $0.93-2.09$ & 0.111 \\
\hline \multicolumn{8}{|c|}{ Previous GPA } \\
\hline Low & 32 & 58.2 & 23 & 41.8 & 1.00 & Reference & \\
\hline High & 12 & 22.6 & 41 & 77.4 & 1.72 & $1.22-2.43$ & 0.002 \\
\hline \multicolumn{8}{|c|}{ Taking FES session on time } \\
\hline No & 28 & 50.0 & 28 & 50.0 & 1.00 & Reference & \\
\hline Yes & 16 & 30.8 & 36 & 69.2 & 1.29 & $0.96-1.73$ & 0.088 \\
\hline
\end{tabular}

* Adjusted each others to risk factors listed on this Table 
Based on the last research on the influence of characteristics on FES model, the most influenced factor on the last grade was the previous GPA, and research was also done at University of Michigan, The Faculty of Public Health. ${ }^{5,6}$

In conclusion, the most influenced factor on Field Experience Study was the previous GPA. While the taking time of FES and gender more likely to influenced the score of FES. There was no correlation between perception and the last grade. It was found there was lack of epidemiology provision.

We suggest that lecture should give more attention to the group of students whose low GPA, male students, and students who do not take the FES lecture on time, in order to encourage them to get better grade. It is also advisable that students take FES lecture on time that is in semester eight from Medicine Education Program. The epidemiology provision handbook should be improved.

\section{Acknowledgement}

The writers are grateful to Prof Bastaman Basuki and Bambang Wispriyono $\mathrm{PhD}$ for their technical assistance and all FES students in even semester 2006-2007 for their achievement in this research.

\section{REFERENCES}

1. Peabody J. Measuring the social responsiveness of medical schools: setting the social responsiveness of medical schools: setting the standards. Acad Med. 1999; 74:559-68.
2. Wannian L, Yin Chan DK. Community health care reform and General Practice Training in China-Lessons Learned. Med Educ On line 2004 [cited 2007 Sept 28]; 9:10. Available from http://www.med-ed-online.org.

3. StataCorp. Stata statistical software: Release 9.0. Texas: College station; 2005.

4. Barros AJD, Hirakata VN. Alternative for logistic regression in cross sectional studies: an empirical comparison that directly estimates the prevalence ratio. BMC Medical Research Methodology [serial online]. Oct 2003 [cited 2007 Aug 1]; 3(21): [13p]. Available from: $\mathrm{http} / / \mathrm{www} \cdot$ biomedcentral.com/1471-2288/3/21]

5. Gibson CC, Graff AO. Impacts of adults preferred learning styles and perception of barriers on completion of external Baccalaureate degree program. Journal of distance education-[cited 2007 November 28]; 17:9. Available from http://caappathabascau.cu

6. Palmer LB, Wojciechowski A. Individual student characteristics: Can any be predictors of success in online classes. Online journal of distance learning administration. 2005. [cited 2007 November 28]. Available from www.ets.org/Media/Campaign/3484/glossary.html

7. Wojciechowski A. The relationship between student characteristics and success in an online business course at west shore community college [dissertation]. Western Michigan University. 2004

8. Cheung L, Khan A. Evaluation for factors related to student performance in a distance-learning business communication course. J Educ Business. 2002; 77:257-63.

9. Lipe MG. Further evidence on the performance of female versus male accounting students. Issues in Accounting Education. 1989;4:144-52.

10. Anonimous. CBME: Community Based Medical Education. Education for health 2002 [cited 2007 Sept 28]; 15:12938. Available from http://furcs.flinders.edu.au/clinical/ cbme/default.htm

11. Abdelmoneim I. Studens perception of the various teaching methods used in the primary health care course in the ABHA, College of medicine. Saudi Medical journal. 2003 [cited 2007 November 28]; 24:1188-91. Available from www.westga.edu 